\title{
Forced conversion during the First Crusade
}

$\mathrm{T}$ he tendency that emerges from Rashi's words reflects a decisive leadership approach, establishing a clear direction of attempting to return converts to Christianity to Judaism. The self-definition of Judaism its leaders sought to establish was that of a religion that felt confident in its ability to deal with Christian theological claims and in its political ability to deal with the threat of forced conversion.

This situation changed during the course of the twelfth century and became far more complex, requiring a different sort of arrangement. During the course of the First Crusade (1096), the Jewish communities that were under the protection both of the emperor and of the bishops, who served as his representatives at the head of cities, were subjected to murderous attacks. The Christians violently forced Jews away from their religion and compelled them to become Christians; those who refused were either murdered or killed themselves as martyrs. ${ }^{1}$ One of the leaders of the Jews called upon the emperor to protect them from the Christians who were setting out to liberate the Holy Sepulcher, and Henry IV responded to their pleas. When the emperor realized that his own warnings had come tragically late, he allowed those who had been forcibly converted to return to Judaism, notwithstanding the protests of Pope Clement III in his letter to the bishop of Bamberg. ${ }^{2}$ On the face of it, the status of the Jews remained as it had been, and they continued to be a strong and self-confident group, enjoying the protection of the rulers. But in practice these attacks created a new reality, both in the eyes of the Christian population and for the Jews of France and Germany. Despite the fact that the actual extent of the attacks upon Jews at the end of the eleventh century was limited (only a few cities were affected: Worms, Mainz, Metz, Cologne, Regensburg, Prague, and perhaps Rouen), these events precipitated a psychological 
change throughout the region. Evidence of this may be found in Jewish writing from the twelfth century, even in those areas where very few Jews were attacked, or none at all. ${ }^{3}$ This new situation found expression in two decisive directions for the Jewish community and its perception of substantive deviation-i.e., conversion to the rival religion. The first pertained to the manner in which Jews dealt with the campaign of forced conversion to Christianity during the Crusades in a number of cities of Germany. The second relates to the Jewish response to the success of the Christian conquest and the establishment of a Christian kingdom in the Holy Land.

At the end of the eleventh century, Christians set forth from Europe on a crusade to free the Holy Land, violently attempting to convert to Christianity the Jews they met on their way. While the harm to Jews was limited to certain cities in Germany, the impression left by this blow went far beyond the actual dimensions of the attacks. It became clear that the Christians were prepared to engage in violent behavior, whose purpose was to force conversion to Christianity - and this in cities where Jewish existence had seemed secure under the protection of the rulers. The Jewish response was to oppose the attempts at forced conversion, to the point of death. This martyr-like response to Christian violence became the preferred mode of Jewish behavior, thereby serving as one of the characteristics of Jewish self-definition. Moreover, in many cases, Jews anticipated the onslaught by Christians and killed themselves before the latter succeeded in forcibly converting them or in killing them. In this way, a considerable number of Jews killed themselves and even their families and children.

The generation that survived the First Crusade, and which educated its children in light of the Jewish response of 1096, left behind a limited number of sources, in prose and piyyut (religious poetry), revealing their attitude to the subject of forced conversion. ${ }^{4}$ The authors of these sources describe the Gentiles - the burghers and the Crusaders - at great length, stressing that the goal of the Christians was first and foremost to convert the Jews to Christianity. Indeed, it was the Jews' description of the Crusaders' unrelenting cruelty towards them, the role played by the burghers, their former neighbors, and the bishops, who in their capacity as protectors of the city were supposed to defend them, that highlighted the missionary aim of Christian behavior which the Jewish texts sought to convey: the Christians were doing everything in their power to bring about the conversion of the Jews, and this was part of the new order in Europe which was the outcome of the Crusade itself. The Jewish texts emphasize this message whenever they write about the Christian perspective. Thus, for example, 'or let them 
adopt our faith and acknowledge its [Judaism's] bastard offspring.' The chroniclers describe incidents in which the Crusaders used the method of 'convert or we cut your throat here and now,' whereas the bishops adopted a more indirect approach. ${ }^{5}$ They did so not just to document the events but, more important, to convince the twelfth-century readers that they ought not to be deceived by 'proper' behavior and offers of protection, as the Christians all had but one goal in mind - namely, to convert the Jews to Christianity.

Twelfth-century liturgical poets likewise placed great emphasis on this Christian goal. Two such writers portray Christian behavior as a trap that had been set in order to ensnare the Jews. In his piyyut, Rabbi Eliezer ben Nathan of Mainz (1090-1170) warns that the Christians are laying a trap for the Jews, and that after they are extricated they will be killed. ${ }^{6}$ Rabbi Kalonymus ben Yehudah writes that the Christians are attempting to convince the Jews to convert to Christianity by using words: 'They start a debate with you and argue ... Their words and promises are snares.' This piyyut emphatically argues that the Christians aspire primarily to convert and not to kill. ${ }^{7}$

Jewish writings describing what happened in Germany when the Crusaders attacked the Jews in the Christian cities have been the subject of extensive research. These writings are the product of members of the first generation following the Crusades, who gathered and documented sources and letters from the First Crusade, constructing an 'educational narrative' of great significance, essentially a code of behavior that was completed even before the Second Crusade. ${ }^{8}$ This generation shaped the consciousness of those Jews who came after the First Crusade, for whom the idea of martyrdom served as a cornerstone of proper Jewish behavior. In this way, they preserved the self-image of their own generation and that of its parent's generation, not only as willing to die in order to prove the truth of the Jewish religion and its victory but also as those who in fact realized this willingness and died as martyrs, and even killed others in order to prevent their 'falling' into the hands of Christians and Christianity. The examples they used needed to be reliable, for they were addressing a public which had itself experienced these events or heard of them from those who had experienced first hand what happened during the course of the First Crusade. Hence, the authors of these chronicles do not conceal the fact that quite a number of Jews had submitted to the forced attempts by the Christians to convert them to Christianity, as they were acting at a time when records and memories of these events were still fresh and familiar. Part of their audience may have itself been forced to convert 
against its will. It was in relation to this that they were able to shape their message and to define their own identity. The message which emerges from the chronicles is that most of the Jews chose to die a martyr's death, and only a small minority preferred to convert to Christianity - and that only in appearance.

There is a great deal of emphasis on the fact that the converts to Christianity were small in number, and that even these did so under coercion, acting unwillingly, when they were surprised, confused, and so forth. They are described with the help of a series of diminutive terms, such as 'very few' or 'a few grains.' The most striking examples occurred in Regensburg and Metz, where there was in actuality massive conversion. According to the chronicles, they were forced down to the river, and they made 'a bad sign over the river.' One should not speak contemptuously of these forced converts: they attempted to return to Judaism, and even when in Christian captivity attempted to observe Judaism as far as possible.' Even this small minority of 'forced apostates' underwent a shocking and terrible experience when they were converted; hence the only conclusion to be reached was that it was better to die a martyr's death than to live as a Christian. In the final analysis, the fashioning of the self- and future-image of the Jews in the twelfth century was of the Jew who was unwilling to become a Christian, even if forced to do so.

There were, however, those who nevertheless did convert. According to the chronicles, all those people who changed their religion did so out of noble reasons; all of them discovered the poverty entailed in their deviation as opposed to the power of the accepted norm; all of them plan for themselves a death that will emphasize the norm, even more so those who kill themselves for the norm. The most striking example of this in the texts is the conversion and death of R. Yitzhak ben David ha-Parnas ${ }^{10}$ who initially agreed to convert to Christianity because he was caught within a net of circumstances that (seemingly) did not allow any other option: he was concerned about his property, he was worried about his sick and elderly mother, and it was clear to him that his children would be taken by the Christians and raised as Christians. The rationale he offered himself was that, as a Christian, he would be able to safeguard his (Jewish) property, take care of his mother, and be close to his children and oversee their education. Nevertheless, at a certain moment, while he was alone in the synagogue opposite the Holy Ark, he understood that none of these reasons could compare to the commended form of Jewish behavior, which he summarizes in a sentence pregnant with significance: 'I will repent, and be innocent and whole before the Lord God of Israel, until I pay him 
with my soul and fall into His hands; perhaps He will act in accordance with His great mercy and I will join my friends, and together with them enter into their realm.' In brief: there are no good reasons for converting to Christianity. Purity is emphasized in contradistinction to becoming a Christian. The dead martyrs doubtless are proof of this, but even those who had, temporarily, joined the Christian religion will in the end understand this. His self-sacrifice, in the final event, will surely come about, fashioned as a sin-offering. This motif likewise emerges from the story of R. Yitzhak ha-Levi, a person who was forcibly converted to Christianity after being subjected to harsh beatings until 'he did not understand anything.' Once he realized what he had done, three days later, he returned to his home in Cologne, stayed there a little while, and then went to the Rhine and drowned himself in the river. He wished, by means of this water, to erase the impression of that water which had turned him into a Christian. His body floated along the Rhine until it arrived at the village of Neuss, where it was expelled onto the shore alongside that of R. Shmuel ben Asher, known as 'the Hasid' ('the pious one'), who had been killed at the riverbank together with his two sons. The story concludes, according to this version, with the words: 'And those two pious men were buried together in the sand on the banks of the river, in a single grave, and they sanctified the name of Heaven before the sun.' The person who had been converted to Christianity by force atoned for his act by a glorious death, and thereby unquestionably merited to be numbered among the martyrs. ${ }^{11}$

The message conveyed by the chronicles regarding those Jews who adopted Christianity during the first half of the twelfth century and, all the more so, of those who remained in the fold, is clearly seen in a section that was definitely written after the events (it is phrased in the past tense) by the editor or the interpreter of the testimonies and stories discussed above. ${ }^{12}$ This section, generally considered a polemic against Christianity, is meant to encourage those Jews living in the difficult circumstances of the beginning of the twelfth century. I would like to call attention to the second half of this section, which should be read as a statement addressed to the Jews, a polemic against their brethren who converted to Christianity in the twelfth century:

Then will they comprehend, understand, and take to heart that in folly they have cast our bodies to the ground, and for falsehood have they slain our saints; that they have spilled the blood of righteous women because of a putrid corpse, and shed the blood of sucklings over the teachings of an agitator and misleader; that his teachings are folly and that they do 
not know their Creator, nor walk on a virtuous path or an upright way; that they were not wise and did not take to heart Who it is that made the ocean and the dry land; and that in all their actions they were fools and simpletons. Good sense abandoned them, and they placed their trust in folly, neither recognizing nor declaring the Name of the living God, King of the Universe, who is Eternal and everlasting. May the blood of His devoted ones stand us in good stead and serve as atonement for us and for our posterity after us, and for our children's children eternally, like the Binding of our father Isaac when our Father Abraham bound him upon the altar. These saints did not say to one another: 'Have mercy on yourselves,' but rather 'Let us cast our blood like water on the ground, and may it be considered before the Blessed Holy One as the blood of the gazelle and of the hart.' ... Thus have attested those few survivors who were forcibly converted. They heard with their own ears and saw with their own eyes the actions of these saints and their utterances at the time of their slaughter and murder. ${ }^{13}$

The aim of the Christian groups which attacked the Jews in the Rhine Valley, according to those sparse and contradictory sources written by the Christians themselves, is unclear. Had they decided to make all of Europe Christian by forcibly converting the Jews to Christianity, or did they wish to make Europe Christian by eliminating all the Jews? ${ }^{14}$ The Jewish sources describing the First Crusade, in both prose and liturgical poetry, make it clear that, as they perceived it, the tendency of the Christians was new, revolutionary, and absolute. The Jews identified the various attitudes of the Christians to the state of Christianity in the world, from which they understood that the Christians were setting out on a crusade to bring about Christian rule over the world, and that the moment the grave of the Christian Messiah in Palestine was freed, it would be impossible, according to this new Christian perception, for there to remain any Jews in the world: either they would convert, or they must die!

This tendency is implied by three chronicles that describe what happened when the Crusader armies passed through the Rhine Valley during the First Crusade. One ought to focus here specifically upon the source written by Rabbi Eliezer ben Nathan (Ra'avan) because he describes the event as he experienced it as a six-year-old child, and what he concluded from it during his mature years (it seems reasonable to assume that he wrote it before the Second Crusade in 1146). He strongly emphasizes that the Christians were interested in converting the Jews and that only after they were convinced that the Jews were steadfast in their refusal to convert were they killed. In 
the eyes of Ra'avan, the options confronting the Christians were either 'we shall take revenge on them and make them cease to be a people' or 'they shall become like us. ${ }^{15}$ Ra'avan underlines this from the beginning of his prose account, in which he describes a Jewish woman who killed herself in Speyer, and goes on to admit the violent conversion of large groups of Jews (who did not kill themselves). Hence, the true intention of the 'Crusaders' is not important, because the Jews defined the Christian intention as imposing Christian religion on all of them, first and foremost on the Jewish children, and whoever would not agree to this would be killed.

The Crusader movement had explicitly folk-missionary characteristics. During the Second Crusade, Bernard of Clairvaux attempted to prevent violent behavior involving either forcible conversion or murder of the Jews, but he was unable to suppress the missionary motif, which had been previously planted in the Crusader propaganda. ${ }^{16}$ Anyone reading the Christian chronicle, The Annals of Würzburg, alongside the writings of Rabbi Ephraim of Bonn, can see this. Rabbi Ephraim of Bonn describes incidents of forced conversion on different dates in the second half of the twelfth century in Germany. There are numerous examples to illustrate that the aim of the Christians was to forcibly impose the Christian religion upon the Jews, and that such conversion would save the Jews from death. According to Jewish sources, even those Jews who were suspected of murder or of blood libels could save themselves from punishment if they converted to Christianity. So long as the overt Christian behavior was such, it was possible to portray the turning of Jews to the Christian world as based essentially upon violent coercion, and thereby mitigate the negative attitude towards Jews who voluntarily converted to the rival religion.

From the beginning of the twelfth century onwards, the norm dictated by the educational process was one of opposition to forced conversion to Christianity to the point of death. In terms of the Jewish self-definition, one might still relate to Jews who had converted through having been forced to do so. But how could one continue relating to them as 'brothers who erred' when the norm required resistance to the point of death, and even putting oneself to death? From the moment that the Jewish self-definition included, in addition to the regular definitions, absolute unwillingness to convert to the rival religion, even by force (i.e., strict and extreme martyrdom behavior, in which the Jew had to be prepared, not only to die, but also to kill himself and his family), the attitude towards the convert to Christianity had to be defined anew, both from the popular viewpoint and from the halakhic perspective. As a result of the strong emphasis on this motif, it became clear that, even if the halakhic attitude 
towards apostates continued to see them in theory as 'brethren' who had been forcibly converted to the rival religion, the basic folk attitude towards them would be different; the very self-definition by the Jew as such made it difficult to continue to relate to them as 'brethren' for whom the door of repentance was always open.

\section{Notes}

1 R. Chazan, European Jewry and the First Crusade, Berkeley 1987; R. Chazan, God, Humanity, and History: The Hebrew First Crusade Narratives, Berkeley 2000; S. Goldin, The Ways of Jewish Martyrdom, Turnhout 2008.

2 A. Habermann, ed., Sefer Gezerot Ashkenaz ve-Zarfat, Jerusalem 1945, p. 94; J. Aronius, Regesten zur Geschichte der Juden im fränkischen und deutschen Reiche bis zum Jahre 1273, Berlin 1902, Nos. 203, 204; J. Elukin, 'The Discovery of the Self: Jews and Conversion in the Twelfth Century,' in: Jews and Christians in Twelfth-Century Europe, eds. M. Signer and J. Van Engen, Notre Dame, Ind. 2001, pp. 63-76.

3 J. W. Parkes, The Conflict of the Church and the Synagogue, London 1934, pp. 79-81; J. Elukin, 'From Jew to Christian? Conversion and Immutability in Medieval Europe,' in: Varieties of Religious Conversion in the Middle Ages, ed. J. Muldoon, Gainesville, Fla. 1997, pp. 171-189.

4 A. S. Abulafia, 'The Interrelationship between the Hebrew Chronicles of the First Crusade,' Journal of Semitic Studies 27 (1982), pp. 221, 239, Nos. 8-15, 61-65; Chazan, European Jewry, pp. 40-49, 307-308, Nos. 7-22. I. G. Marcus, 'Review of Robert Chazan, "European Jewry and the First Crusade,"' Speculum 64 (1989), pp. 685-688; I. G. Marcus, 'History, Story and Collective Memory: Narrativity in Early Ashkenazic Culture,' Prooftexts 10 (1990), pp. 365-388; R. Chazan, 'Factivity of Medieval Narrative: A Case Study of the Hebrew First Crusade Narrative,' Association for Jewish Studies Review 16 (1991), pp. 31-56; Goldin, The Ways of Jewish Martyrdom, pp. 85-162; E. Haverkamp, Hebraische Berichte uber die Judenverfolgungen wahrend des ersten Kreuzzugs, Monumenta Germaniae historica. Hebraische Texte aus dem mittelalterlichen Deutschland, Hannover 2005.

5 Habermann, Sefer Gezerot Ashkenaz ve-Zarfat, pp. 24, 27, 29, 41, 44, 46, 63, 97. English translation, S. Eidelberg, The Jews and the Crusaders, Madison 1977.

6 Habermann, Sefer Gezerot Ashkenaz ve-Zarfat, p. 85.

7 Habermann, Sefer Gezerot Ashkenaz ve-Zarfat, pp. 64-66. The imagery is taken from Jeremiah 5:26, according to the King James version: 'For among my people are found wicked men: they lay wait, as he that setteth snares; they set a trap, they catch men.' It is worthwhile to note Rashi's explanation of this verse: 'When the trap that the hunter sets to snare foxes in the woods wounds the leg which is caught inside, it clamps down and seizes his leg and he is trapped; it is [apparently] called "piege," which comes from "pied” [in French].' 
8 S. Goldin, 'The Socialisation for "Kidush ha-Shem” among Medieval Jews,' Journal of Medieval History 23 (1997), pp. 117-138.

9 Habermann, Sefer Gezerot Ashkenaz ve-Zarfat, pp. 23, 67-68, 81, 103.

10 This is an example with which two of my colleagues, Israel Yuval and Jeremy Cohen, have dealt. Yuval attributed to the process of this man's death a model of a ceremony of offering a sacrifice, whose purpose was to bring about the 'vengeful redemption'-I. J. Yuval, Two Nations in Your Womb, Berkeley 2006, pp. 144-154; J. Cohen, Sanctifying the Name of God, Philadelphia 2004, pp. 91-101; J. Cohen, 'Between Martyrdom and Apostasy: Doubt and Self-Definition in the Twelfth-Century Ashkenaz,' Journal of Medieval and Early Modern Studies 29 (1999), pp. 431-471.

11 Habermann, Sefer Gezerot Ashkenaz ve-Zarfat, pp. 44, 78.

12 Habermann, Sefer Gezerot Ashkenaz ve-Zarfat, p. 43.

13 Regarding the Christians and the Jewish behavior, see: Habermann, Sefer Gezerot Ashkenaz ve-Zarfat, pp. 26-27, see Eidelberg translation The Jews and the Crusaders, pp. 25-26: 'You are the children of those who killed our object of veneration. We are his children and it is therefore obligatory for us to avenge him. Your God has never been at peace with you.' The Jewish reaction: 'When we heard these words, our hearts trembled and moved out of their places. We were dumb with silence, abiding in darkness, like those long dead, waiting for the Lord to look forth and behold from heaven.'

14 K. Stow, 'Conversion, Apostasy, and Apprehensiveness: Emicho of Flonheim and the Fear of Jews in the Twelfth Century,' Speculum 76 (2001), pp. 911-933; D. Malkiel, 'Destruction or Conversion: Intention and Reaction, Crusaders and Jews, in 1096,' Jewish History 15 (2001), pp. 257-280.

15 Habermann, Sefer Gezerot Ashkenaz ve-Zarfat, p. 72.

16 A. Haverkamp, 'Baptised Jews in German Lands during the Twelfth Century,' in: Jews and Christians in Twelfth Century Europe, eds. M. A. Signer and J. Van Engen, Notre Dame, Ind., pp. 261-262, esp. notes 36-42. 